\title{
Transposition
}

Musique et Sciences Sociales

$4 \mid 2014$

Musique et conflits armés après 1945

\section{Borrowed Tunes. Commando and Morale Booster Songs of RUF Fighters in the Sierra Leone War}

Mélodies d'emprunt. Chants de commandement et de stimulation morale parmi les combattants du RUF durant la guerre civile de la Sierra Leone

\section{Cornelia Nuxoll}

\section{OpenEdition}

\section{Journals}

Édition électronique

URL : http://journals.openedition.org/transposition/598

DOI : 10.4000/transposition.598

ISSN : 2110-6134

Éditeur

CRAL - Centre de recherche sur les arts et le langage

Référence électronique

Cornelia Nuxoll, «Borrowed Tunes. Commando and Morale Booster Songs of RUF Fighters in the Sierra Leone War », Transposition [En ligne], 4 | 2014, mis en ligne le 15 juillet 2014, consulté le 20 avril 2019. URL : http://journals.openedition.org/transposition/598 ; DOI : 10.4000/transposition.598

Ce document a été généré automatiquement le 20 avril 2019

La revue Transposition est mise à disposition selon les termes de la Licence Creative Commons Attribution - Partage dans les Mêmes Conditions 4.0 International. 


\title{
Borrowed Tunes. Commando and Morale Booster Songs of RUF Fighters in the Sierra Leone War
}

\author{
Mélodies d'emprunt. Chants de commandement et de stimulation morale parmi \\ les combattants du RUF durant la guerre civile de la Sierra Leone
}

\section{Cornelia Nuxoll}

\section{Introduction}

Situated in music sociology, this article will explore the role of commando and morale booster songs among Revolutionary United Front (henceforth RUF) combatants in the Sierra Leone war of the 1990s. It will look at the tunes that accompanied military training and combat activities and more generally study the role of music to help generate social cohesion and sustain collectivities. Two aspects will be under consideration here: on the one hand, the article will examine how the songs elicit desired bodily and cognitive affects advantageous for soldiering. On the other hand, it will analyse the diverse ways in which songs have been reworked from other performance contexts and placed into a conflict setting.

The article will look into how music generates beneficial physical and emotional responses for combatants to create a sense of synchronicity and cohesion during military exercise and how music instigates zeal and bravery in the fighters. Most of the songs dealt with in this paper are (partial) contrafacta of Liberian Gio [Dan] songs, which were incorporated from other cultural practices and contexts and already played a role as motivational songs in the Liberian civil war. Special focus lies on the use, the fluidity, and the formability of the songs, as well as the ingenuity of its performers to recontextualise these songs. By fitting the songs into their war experience, combatants render them meaningful despite obvious language barriers and beyond their textual properties. 
The following article will provide some initial information on the war situation in Sierra Leone and assess the role of Liberian Gio fighters and their songs. By means of several song examples, it will then proceed to investigate the practical use of the rebel commando songs among Sierra Leonean insurgents.

\section{The Sierra Leonean War: A Brief Account}

4 After decades of state decline due to bad governance, political corruption, and economic failure, the then ruling All People's Congress (APC) government had slowly but surely eroded Sierra Leone, thus creating the conditions for a collapsing state. In particular, young people experienced the injustices and poor livelihood prospects given APC's selfserving rule, mismanagement, and deterioration of institutional processes. These conditions contributed significantly to and sustained the war, which raged in Sierra Leone from 1991 to $2002 .^{1}$

In March 1991, the RUF launched its insurgency into Sierra Leone from neighbouring Liberia, entering the Kailahun and Pujehun Districts with support from the Liberian Special Forces of Charles Taylor's National Patriotic Front of Liberia (NPFL) rebels who had launched their own civil war in Liberia in December $1989 .{ }^{2}$

The RUF claimed to liberate the civilian population from a 'rotten system', aiming to overthrow the then ruling APC government. The movement's moots 'No more slave, no more master' and 'Arms to the people: power to the people and wealth to the people' criticised patrimonial structures and political clientelism. As stipulated in their political manifesto, the insurgents demanded democracy, equal opportunities, social justice, free health care, and education, and leaned on pan-Africanistic rhetoric without ever specifying what kind of shape a RUF-run administration would take. ${ }^{3}$

7 The RUF's first control sectors in the Kailahun and Pujehun Districts were known core areas of political opposition and dissent. For this reason, the civilian population was initially taken with the RUF revolution and the movement gained at least some voluntary followers, predominantly young males. Early on in the war, however, the rebellion quickly revealed itself to be an abusive movement, which sustained itself through looting, the illicit extraction of diamonds, and forced conscription. The atrocities, which were inflicted on innocent people, soon resulted in a complete loss of support from the civilian population. The Sierra Leonean civil war is indeed infamous for its flagrant human rights violations, its signature atrocities of limb amputations, and the widespread forced, coerced, and voluntary involvement of juvenile and child combatants.

Within scholarly discussions, the nature and motivation of the RUF movement is hotly debated. Certainly, there is a stark contrast between the political claims the rebels made and their heinous actions of impunity. The extreme violence towards civilians in this conflict, the 'chameleonic character' and 'factional fluidity's of combatants, and the shift from political overthrow towards the selfish and opportunistic pursuit of economic benefits to prolong rather than end the war ${ }^{5}$ have played into labelling the Sierra Leonean struggle as a 'senseless war' ${ }^{\prime}$ in terms of political reformation, simplifying it as a resource or diamond war which was only driven by greed rather than grievance. ${ }^{7}$ The Sierra Leonean scholars Ibrahim Abdullah and Patrick Muana largely deny the RUF any political agenda and discard its combatants as members of the 'lumpenproletariat', namely uneducated, unemployed youths and thugs. ${ }^{8}$ When looking at the Sierra Leonean 
conflict, journalist Robert Kaplan sees his Afro-pessimistic analysis of the continent's demise into brutal wars confirmed, an analysis which social anthropologist Paul Richards critically coined an emerging 'New Barbarism'. ${ }^{9}$ Political scientist William Reno and Paul Richard ${ }^{10}$ see the rise of the conflict as the outcome of a patrimonial crisis. Moreover, Paul Richards, Krijn Peters and others have argued that the high number of underage fighters reflects a 'crisis of youth' or an 'agency of youth', suggesting that juvenile combatants possess a political consciousness and regarding their enlistment, even when coerced, as an opportunity to escape and rectify the political, social, and economic marginalization they felt. ${ }^{11}$ The Sierra Leonean scholar and political scientist Jimmy D. Kandeh cautions that greed as motivation may have prolonged the war but it was not decisive to its inception. He sees the Sierra Leonean insurrection as a legitimate political struggle, which then evolved into a form of criminal warlordism..$^{12}$

9 All things considered, the RUF movement assembled a heterogeneous group of combatants with different agendas. Where early voluntary enlistment seemed to be motivated by grievances, the rebellion became increasingly more brutalized and criminalized, replacing need and creed for greed as the most crucial element to prolonging the war for exploitative reasons.

This article draws on qualitative interviews with former RUF combatants gathered during fieldwork I conducted in Sierra Leone in winter 2010/2011 and again in winter 2011/2012. ${ }^{13}$ Most of my interlocutors come from the initial incursion areas where they joined the RUF movement early on and most of them stayed with the insurgency group until its final days. The majority of men were in their mid- to late teens when they became involved in paramilitary activities in the early 1990s.

11 My sample suggests that early recruits were more likely to join the RUF out of political conviction and perceived grievances than later recruits who were, given the RUF's need of manpower, primarily forcefully and more arbitrarily recruited. Others may have joined the movement of their own accord, driven by their own agenda of self-preservation or motives of self-enrichment and power. There also seems to be a connection between early (voluntary) recruitment and the knowledge of commando songs, since later events in the war no longer allowed for the forcefully conscripted recruits to undergo the same timeconsuming military training the pioneers had received.

The military training, which early Sierra Leonean recruits undertook, lasted from a couple of weeks to a couple of months. During this time the new conscripts were not only subjected to military practices, discipline, and conduct, but were also introduced to the commando song repertory of their training instructors, the Liberian Special Forces, who were predominantly of Gio origin. In the following, I will briefly describe how the NPFL Gio combatants found their way into the cadre of the RUF insurgency by outlining some aspects of the Liberian war, which ensued two years before the launching of the Sierra Leonean conflict.

\section{Gio Dominance within NPFL Rank and File}

Nimba County, geographically Liberia's largest political subdivision and bordering with Ivory Coast and Guinea, is the home of the Gio (Dan) and Mano (Mah/Man) ethnic groups. ${ }^{14}$ Both ethnic groups are culturally and linguistically closely interrelated. When Charles Taylor led his NPFL rebel faction from Ivory Coast into Liberia via Buutuo on December 
24, 1989 in order to overthrow president Samuel K. Doe, they set up their first paramilitary camp in Gborplay, another border town in Nimba County. Both Buutuo and Gborplay are predominantly inhabited by Gios. Taylor recruited heavily from both Gio and Mano ethnic groups in the area and most high-ranking officials within the NPFL insurgency were of Gio origin. ${ }^{15}$

Taylor endeared the hearts of Nimbaians when he claimed to be General Thomas Quiwonkpa's successor, drawing on the popular Gio figure who died trying to overthrow the Liberian president Samuel K. Doe in 1985. The former commanding general of the Armed Forces of Liberia (AFL) Quiwonkpa, often remembered by Liberians as "Tom", was venerated as a heroic martyr and liberator of his country and many Liberians hoped for the unlikely outcome that Quiwonkpa had actually somehow escaped Doe's soldiers unscathed and would return eventually. After Quiwonkpa's failed coup, Doe ordered Nimba County to face severe reprisals, since most of the coup plotters were of Gio and Mano origin. These measures only fuelled tensions and perceptions regarding Doe's preferential treatment of his own ethnic group in government and army, the Krahn. Charles Taylor harnessed the strained relations and further ethnicised the conflict by deliberately recruiting from the Gio and Mano ethnic groups to create somewhat of an ethnic counterweight to the predominantly Krahn army loyal to the president, mobilizing the rebellion towards a genocidal campaign against the Krahn and their Madingo allies. ${ }^{16}$

Another prominent key figure of Gio origin during the first Liberian civil war was Prince Yormie Johnson, who served as aide to Quiwonkpa and later as Taylor's Chief Training Officer within the NPFL. In the early stages of the war, however, internal rivalries caused a rift between Taylor and Johnson, who decided to form the breakaway faction Independent National Patriotic Front of Liberia (INPFL) under his leadership. Being a strong force, the INPFL controlled strategic points within the capital city Monrovia and they were influential in catalysing the deployment of Economic Community of West African States Monitoring Group (ECOMOG) cease-fire monitoring groups. In September 1990, Johnson's men seized, tortured, and murdered president Doe. By the end of 1992 however, the INPFL's role in the conflict had considerably declined and the faction eventually dissolved altogether due to internal tensions and lack of consensus regarding their own positioning towards and cooperation with NPFL, ECOMOG, and the interim government.

With regard to NPFL rebel factions being predominantly comprised of Gio fighters, both my Sierra Leonean and Liberian interlocutors stated that the Gio tribe was reputed for producing great and fierce warriors. Moreover, in comparing the Gio with their close relatives, the Mano, Gio people are often described as bold, boastful, and speaking up openly whereas the average Mano man is stereotyped as quiet, contemplative, and deep, making him less of a fighter as a direct result.

You see wetin [what]..., in Liberia [you] see: there are some tribes in Liberia, they are war-like people. You see that the Gio, they are war-like people, all their activity na [is] war activity. Yes. They are very brutal. Up to now.

(Interview with B., former RUF combatant, Makeni, $30^{\text {th }}$ Dec 2012)

Certainly within Liberia, the Gio people are renowned for their musicality and are often regarded as some of the best singing groups in the country. The supremacy of Gio fighters within the ranks of the NPFL clearly shaped the repertory of commando songs towards being Gio dominated, which will become apparent below. ${ }^{17}$ 


\section{RUF's Initial Insurgency and the Involvement of NPFL Combatants in the Sierra Leone War}

On March $23^{\text {rd }} 1991$, Liberian NPFL leader Charles Taylor facilitated the RUF's initial insurgency, which entered Sierra Leone through the border town Bomaru from Liberia into the Kailahun District. A second group of rebel fighters invaded Sierra Leone's Pujehun District. It has been suggested that Taylor provided RUF rebel leader Foday Sankoh with some of his fiercest NPFL fighters for the RUF invasion. These Special Forces were mostly of Gio origin. ${ }^{18}$ Both Taylor and Sankoh had met and undergone self-defence paramilitary training in the late 1980s in Libya where they had forged a mutual agreement to assist one another in the launching of their respective incursions. ${ }^{19}$

Besides securing territory and establishing military camps, the despatched NPFL Special Forces were assigned the task of training the Sierra Leonean vanguards (which was partly done within Liberia already) as well as the newly recruited combatants once the rebellion had entered Sierra Leone. Notwithstanding, early on in the war it became apparent that the Liberian forces neither identified with nor considered the - however weak - political agenda of the RUF with regard to their own military conduct. During the interviews, former RUF combatants were eager to point out that it was the Liberian forces within the RUF that introduced the looting of property and the committing of atrocities against the Sierra Leonean civilians, the very group the RUF had claimed to liberate from the personal rule of the APC government.

Training started. We [the new recruits] were there for one month to two months, they [the NPFL Special Forces] trained us fully in all activities, all rebel tactics were..., guerrilla tactics were taught, we were brainwashed, we were briefed a little bit about the ideology. We didn't get the ideology fully from the Liberian guys [however]. Few of the Liberian guys were among them [those who were ideologically driven] of course. I cannot hide this from you. Liberian guys were more..., you know, I mean, to the front[line] than our Sierra Leonean brothers. So we bought [adapted to] their ideology, their guns were behind us, so there was no way for us [to challenge their conduct], so we just have to bow down, subdue and submit ourselves. We cooperated, we were trained. The training we've had..., I admired the training now because we were physically fit and young men admired the training.

(Interview with V., former RUF combatant, Freetown, $2^{\text {nd }}$ February 2011)

In general, RUF fighters blame the Liberian Special Forces for stifling their revolutionary efforts at birth. Where it seems that NPFL fighters could initially act with impunity, over time however, RUF fighters appear to have emancipated and united themselves against the deviating Liberian fighters within their ranks. By the end of 1992, RUF combatants had dispelled their Liberian comrades altogether, except for those who were loyal to their cause. A former RUF combatant who was with the RUF throughout the whole course of the war echoes these sentiments by saying:

The NPFL [...] were not trained to be political fighters. But the RUF at that moment was really engaged. They..., we were having a political ideology. And they were organised to continue their, the revolutionary operation. Understand? In fact, that was one of the reasons why we fought against the NPFL [in order] to drive them [out] because they were harassing our [Sierra Leonean] people, you know, kil..., wounding people, killing them, you know, introducing different, different type of things in[to] the movement. That was against [...] the RUF [...].

(Interview with F., former RUF combatant, Freetown, $22^{\text {nd }}$ January 2011) 
er eager they may have been to blame their Liberian colleagues for the atrocities, circumstances have shown that attacks against the civilian population did not cease after the expulsion of the Liberian Special Forces. The violent example the NPFL fighters may have provided, the power of the gun to command respect, and recognition as well as economic incentives of personal gain, may actually have been more significant in fuelling the combatants' actions than adhering to ideology or moral and military conduct after all. 20

Before tensions between Special Forces and RUF combatants flared up and ultimately led to the banishment of the Liberian faction, however, the presence and influence of Gio fighters were noticeable on the military training and musical level within the movement.

\section{Music in the Military, Music in War}

Music has accompanied and stimulated battle and military life for centuries. Historical records suggest that the use of music as an essential tool to accompany warring activities dates back to biblical times. Music not only inspires troops for combat, it was also used to convey signals and commands on the battlefield and during drill exercises. ${ }^{21}$ Furthermore, there is general accord that the joint engagement with music endows social cohesion and may bring about a shared sense of identity within performing groups. Musical dissemination and performance is not only a means of expressing social grouping, it may constitute, structure, and maintain collectivities. ${ }^{22}$

In their excellent study on music and social movements, Eyerman and Jamison draw on music as 'cognitive praxis', as both knowledge and action, interpretation, and representation. It is this that encourages social solidarity through music: ${ }^{23}$

Music as experienced and performed within social movements is at once subjective and objective, individual and collective in its form and in its effects. Through its ritualized performance and through the memories it invokes, the music of social movements transcends the boundaries of the self and binds the individual to a collective consciousness. ${ }^{24}$

Historian William H. McNeill coined the term 'muscular bonding' to describe a specific potency and emotional response in human beings moving together rhythmically in dance and drill. ${ }^{25}$ McNeill draws on his own experiences in the US army in the 1940s when describing how a prolonged movement in unison such as drill exercises and marching facilitated 'a sense of pervasive well-being', 'a strange sense of personal enlargement; a sort of swelling out, becoming bigger than life, thanks to participation in collective ritual'. ${ }^{26}$ McNeill further argues that well-drilled troops are more efficient in combat due to the rehearsing of the actual battle performance as part of the military drill. Repetitive work and exercise not only become more bearable but productivity may actually increase when labour and training are performed rhythmically and as a group. McNeill observes that by means of emotional bonding through rhythmic muscular movement, human beings experience the blurring of self-awareness and the fading of individual differences, which in turn foster the strengthening of group solidarity and help create the necessary state of mind for whatever joint task is to come. ${ }^{27}$ Music as part of military activity not only helps to generate eagerness in the fighters but also directly contributes to the triggering of beneficial physical responses. Music is intrinsic to drill exercise, and joint singing may temporarily unify soldiers in physical

Transposition, 4 | 2014 
expression and ideology to persevere, endure hardships, and fight adamantly. ${ }^{28}$ In her article on US soldier songs during the First World War, Christina Gier emphasizes how songs and the singing of the songs shaped and were supposed to shape the fighting soldier's perception and military experience of the war. Through the performing of music, an attempt was made to promote mental, moral, and physical manhood in the fighters, increase their combat efficiency, and regulate the soldiers' emotions in line with their military duty. Moreover, group singing was intended to ensure obedience and selfsacrifice, and ultimately to instil identification with all aspects, implications, and ideologies of war. In this regard, the realities and hardships of war would often be concealed, obscured, or embellished in and through songs. ${ }^{29}$

27 Very little research has been done so far on the interconnections of music 'for war' and music 'in war' in contemporary African conflict settings. There is for example a vast amount of research dedicated to praise poetry, as well as literature on music as a means of political expression, protest, and resistance in relation to the African continent, but few works have directly dealt with (the use of) musical repertoires in contemporary African war scenarios. ${ }^{30}$

My research is less interested in music analysis of musical pieces that were either explicitly composed for a warring environment or otherwise found their way into a collection of commando songs considered useful or popular by combatants for mobilisation and motivation purposes. Instead, I am interested in examining why people incorporate music into waging war, what functions music fulfils, and how. In this regard, human beings find resourceful ways of applying music and look for qualitative, activating as well as negotiating factors in music, which prompt certain physical and psychological triggers and responses. Therefore, and by virtue of the fact that there is a lack of publications available with regard to contemporary African wars and the role of music in it, I draw on other conflict examples outside of the African continent, which have been studied for their musical components to demonstrate and substantiate how and why people in war use music. The intention is not to compare or even equate the different wars and conflicts from different cultures and epochs with one another but rather to highlight (without suggesting a typologisation) that similar dynamics are at work in situations where human beings are engaged in conflict, and that music functions to make sense of war and conflict and generate collective experience.

\section{Gio Commando Songs}

In 1991, NPFL combatants were despatched to Sierra Leone to assist in launching the RUF insurgency in the neighbouring country. The Gio dominance within the NPFL and their role as military training instructors for Sierra Leonean vanguards and newly recruited Sierra Leonean Junior Commandos in military camps is the reason why the RUF commando songs were coined and sung in the Gio [Dan] language. Mapping the role of Gio commando songs within the RUF rebellion also adds weight to Liberian warlord Charles Taylor's substantial involvement in the Sierra Leonean conflict.

Apart from conveying basic military and weaponry knowledge as well as conducting physical exercises, the Liberian training instructors introduced the recruits to the Gio song repertory as part of the commando drill which already played its part in the Liberian civil war under Charles Taylor. A lot of the songs, which had accompanied NPFL activities, were reapplied as part of the military training of Sierra Leonean fighters. The 
pool of songs comprised jogging songs to inspire zeal in the fighters, praise songs for the rebel leadership, songs of advice, taunting songs or revenge songs, and more generally folk songs which weren't necessarily attuned to the war effort, to name but a few. Unlike the more sophisticated and often figurative rhetoric of praise poetry and the scholarly understanding of African verbal arts as texts or narratives of history and literature, ${ }^{31}$ most of the songs presented here are simpler in nature and have straightforward melodies, catchy tunes, steady rhythms, and easily memorable lyrics. Usually they are based on a typical call-and-response pattern, which allow for infinite variation and lyrical flexibility in the call phrase followed by the repetitive choral response.

31 The alternation between variation and repetition not only sustains the piece for the needed duration but the song structure of soloist and chorus also facilitates group participation and ultimately group identity and solidarity. There is general accord that actively engaging in music rather than simply listening to and consuming it makes the experience of the occasion more direct and renders the social context it is performed in more potent and effective. Thus, music as oral tradition is vital for sustaining African community life; it is not only a way of aesthetic or artistic expression but it accompanies social occasions and is often performed in a specific context or social set-up to generate social action. ${ }^{32}$

The Liberian drill and jogging songs are particularly upbeat and correspond well with the marching pace and other physical exercises of the military training. It is noteworthy that RUF combatants still remembered quite a number of songs even ten years after the war was officially declared over. During interviews, only a few combatants needed prompting but then immediately recalled the tune and lyrics of the songs and enthusiastically joined in the singing. In addition, it is significant that the Gio songs remained popular with RUF pioneers throughout the whole course of the war. Despite the fact that incongruities between the Special Forces and the Sierra Leonean combatants ultimately led to the expulsion of Liberian fighters within their cadres, it did not entail the dismissal of their songs.

Interestingly, only few songs were newly composed pieces and therefore actual products of the Liberian, let alone the Sierra Leonean conflict. In fact, most songs originated from other contexts and cultural practices within Gio society where they were orally transmitted and regarded as public property. Several songs were part of traditional folk songs, or, to suggest Klusen's less controversial term, 'group songs' [Gruppenlied], including love songs and songs of entertainment; but for the most part songs were taken from the repertory of competitive and taunting songs as they are used in the context of soccer games, races, and election campaigns. ${ }^{33} \mathrm{~A}$ few songs were borrowed from the Boy Scout movement and found their way into the repertory of both the Liberian and Sierra Leonean insurgency. ${ }^{34}$ The Boy Scout drill song 'Are you a commando?' for instance, could easily be incorporated into the war effort as a marching song. The soccer song 'We are qualified' was originally a competitive song with insulting lyrics to humiliate one's opponent. During the war, the song was redrafted into a song leading up to and eventually marking the successful graduation from military training by singing:

Oh, CO [Commanding Officer] Sankoh [RUF rebel leader] yeh, hey

Don't you worry, ye

Don't you worry, we are qualified

We can take a lead, hey

To any battlefront

Don't you worry, we are qualified 
Oh, we are freedom fighters, hey

We are qualified

Don't you worry, we are qualified ${ }^{35}$

Another popular commando song was 'E zo lo wah e gay', a rather poetic Mano (Mah/ Man) song which can be translated as 'Your heart will hurt in your stomach'. In the Mano's and Gio's worldview, the heart is the centre of human thinking, and the heart is located in one's stomach. Other suggested translations are 'Your heart will hurt' or 'You will be frustrated or emotionally hurt'. 'E zo lo wah e gay' was popular as a soccer competition song prior to the war and was sung to announce to the opponent that he will lose and take the beating in the coming match, thereby intimidating him. The competitive, taunting, and threatening character of the song made it very suitable for adaptation into a war setting.

L: Zo lo, le Ma way! / Your mother's heart will be frustrated!

R: Zo lo! / Your heart will!

L: Ay, Foday Sankoh le Ma way! / Foday Sankoh's mother! [calling her attention]

R: Zo lo wah e gay! / Your heart will burn in your stomach

[...]

L: Oh, tactical commando moving ay!

R: Zo lo wah e gay! / Your heart will burn in your stomach!

L: When we're moving tactically

R: Zo lo! / Your heart will!

L: All the fucked up soldiers run away yah!

R: Zo lo wah e gay! / Your heart will burn in your stomach!

[...]

L: When we are moving for battlefront ah

R: Zo lo! / Your heart will!

L: Nobody fuck up, we don't stop oh

R: Zo lo wah e gay! / Your heart will burn in your stomach! ${ }^{36}$

Again, the song allows for infinite variation to narrate tactical manoeuvring and battlefront experiences. The inflammatory slogans, the boastful character, and the postulation of strength of their own rank and file are upheld as main themes throughout the song.

The original Mano soccer version predating the war would include lyrics saying 'Zo lo, peh li mi leh le maa wee' ('Your heart will be frustrated', addressing a lover's mother) followed by the response 'Zo lo wah gay' or 'Ay, me leh peh keh peh lah keh o!' ('Oh, nothing happens to you if you haven't done anything'). A different version of ' $\mathrm{E}$ zo lo wah e gay' would for instance focus on another aspect of the war experience and thus name and praise the weapons the combatants were carrying and relying on:

As you are listening to this song, it is just a motivational song when the combatants are together. Moving, on a battlefield. Even after the battlefield they are [at] base, this song can always be sung by the group as a whole, enjoying themselves. [...] It is just as I have said, a motivational song. Look at this Zulay limanway: ${ }^{37}$ [sings] "Zulay, eh my GMG [Grenade Machine Gun] will carry me". Praising even the weapon that they were carrying. Praising even the weapons like the GMG, [sings] "will carry me". Praising his own weapon, praising the [unintelligible], another heavy weapon.

(Interview with V., former RUF combatant, Freetown, $28^{\text {th }}$ January 2011)

The practice of borrowing tunes from other contexts and, if necessary, overwriting and assimilating songs emanating from opponents is not a new phenomenon. The substitution of one text for another without significant changes made to the melody of a song is known from other historical and social contexts. Agents from other conflicts and wars 
have made use of established songs in order to appropriate them for their own cause. Be it because of lack of one's own compositions or simply seeing the appeal and potential of an already established and popular song for their own cause, the creation of contrafacta ${ }^{38}$ is an efficient and fast way of disseminating new material in a tried and tested form. ${ }^{39} \mathrm{In}$ this regard, Agu points out that the appropriation of songs is more powerful and direct for reasons of 'adaptability', 'spontaneity', and dissemination and is thus preferred to absorbing printed works for a warring cause..$^{40}$

As illustrated in his book Battle Hymns on the music of the American Civil war of the $19^{\text {th }}$ century, historian Christian McWhirther has demonstrated how many of the song lyrics were constantly in flux and went through multiple and lyrical iterations to suit specific soldier sentiments and situations throughout the course of the war. Even the meanings of songs seemed to be rather transient, as many songs took on new associations when they left their original contexts and were put to use elsewhere. Although the American Civil War produced a lot of new compositions, the factions often made use of existing tunes and furnished them with new lyrics. Similarly, some of the war's most popular songs were based on traditional melodies. Sometimes borrowed songs ascended to become unofficial anthems but mainly became meaningful pieces due to their ascribed associations and less so by what they actually said. Regiments would also create their own songs to give them their personal touch and to commemorate victorious events and praise particularly brave soldiers. ${ }^{41}$

When looking at the Sierra Leonean case, the incorporation of Liberian songs did occasionally involve some adaptations, revisions, and alterations of lyrics to make them fit the war context more accurately. This suggests that they negotiated the songs on a case-by-case basis, sometimes prioritising lyrics over musical structure alone according to their respective needs. Some songs literally remained unchanged as they were taught, whilst other songs were furnished with added lyrics or had entire lines replaced accordingly. In the latter case, it was a common practice among RUF combatants to hold on to the chorus or main theme of the Gio songs but they would add phrases in Krio, Sierra Leone's Pidgin English and lingua franca, to lend some personal references from their own war experience to the songs. ${ }^{42}$

Another prominent adaptation was the Gio song 'Yah nu neh' which can be translated as 'Why are you not coming?' or 'Where are you?'. Originally, it was a casual boyfriendgirlfriend song predating the war. It was sung in Liberian villages and towns in Nimba County when one missed his or her lover, adding the name of the person in question to the lyrics. The song was reworked for the Liberian war and turned into a somewhat lamenting praise song for the rebel leadership. Although it lost its romantic component, the adaptation maintained its mournful character. In the song, the combatants would ask for the whereabouts of their leader Charles Taylor and other key commanding officers, showing respect for their superiors and voicing the need for guidance in times of their absence. The song structure allows for infinite possibilities of calling somebody's name.

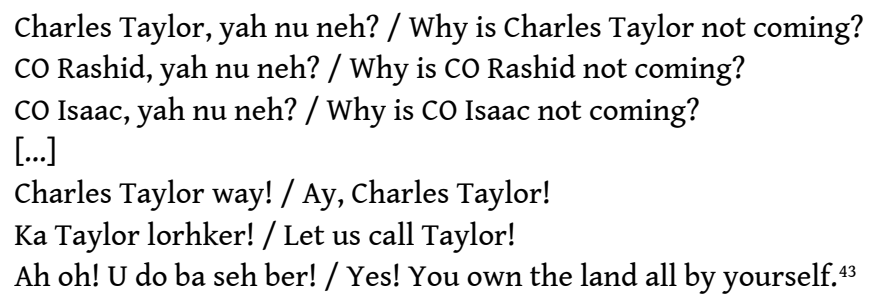



seize and control the country. It is noteworthy that this last line of the song was only added during the war to create a more direct link to the on-going struggle.

The following two statements illustrate the local transfer of the 'Yah nu neh' song to Sierra Leonean RUF combatants. In the first quote the fighter actually knows the meaning of the song lyrics and is also able to pronounce the words correctly whereas the second combatant reveals that the song background was unknown to him and his comrades. For this reason, the latter contextualized and received the song differently, but by no means was the song less effectively used. As a result of the appropriation, the call for Liberian rebel leader Charles Taylor was replaced with the name of the Sierra Leonean rebel leader Foday Sankoh.

That is Gio language, a Liberian tribe, [starts singing] 'Foday Sankoh yah nu neh, Foday ...'. Sankoh was lost from us for quite some times, ${ }^{44}$ [sings] ' $e$ h eh', when can we find him? It is the interpretation [translation], it is a Gio music. We had Liberians that dominated the vanguards, who came to really launch the revolution. But by then, most of the songs we used to sing were originated [originating] from them [...].

(Interview with D., former RUF radio operator, Kailahun, $13^{\text {th }}$ Nov 2010)

You see, I don't really know the meaning. Foday Sankoh [sings] 'yah nu nah', you know. Sometime when we are happy, like if I went to attack a village or a town tomorrow, then today we will be happy, we'll be singing, we have that zeal to move, in case of any obstacle, we will be happy to clear the obstacle. So as a result we sing, we say [sings] 'Foday Sankoh, yah nu nah'.

(Interview with A., former RUF combatant, Freetown, $17^{\text {th }}$ December 2011)

When focusing on the lyrics of the commando repertory, within Liberia the Gio songs were perhaps already known but were certainly understood by Gio combatants (and Gio speakers more generally) when performed as part of the Liberian civil war. Additionally, the communal origin of the musical pieces may have provided some kind of evocative referral to their Nimba homeland..$^{45}$ Conversely, the songs' textual meaning was - for the most part - literally 'lost in translation' and the origin of the songs remained unknown to the Sierra Leonean combatants who were taught the songs as part of their military training with the RUF. Interviews have shown that the overall amount of former RUF combatants were unaware of what the Gio songs were about, let alone where they came from other than that the Gio Special Forces introduced them to the Sierra Leonean struggle. ${ }^{46}$ When asking a former bodyguard of rebel leader Foday Sankoh whether the training instructors explained what the lyrics of the Gio commando songs meant or where they originally came from, significantly, he remarked 'No, they do not explain. It [the songs] was only meant to boost the morale'. This statement as well as the numerous descriptions by RUF fighters of how meaningful, powerful, and inspiring the Gio songs were despite the obvious language barrier clearly challenges the preconception of music only being able to have an impact and convey a message because it contains lyrics.

Music works as a whole and also because it is performed or consumed within a particular context. It is a medium that communicates and operates semiotically, thus calling upon content and meaning beyond its lyrics. Music is rather charged with meaning due to the subject handling it, performing it, consuming it, and contextualising it. It is the subject who renders music meaningful because it is embedded within a specific performance context. Music can affect human beings precisely because music's affect is attributable. What is often referred to as the 'power of music' cannot be abstracted from its use. Music should be understood as a device rather than a simple causal stimulus that human beings 
turn to in order to gain access to and trigger emotional experiences and physical responses. Music is widely used to influence mood by means of intensifying or releasing existing emotions: it relaxes people, it helps them to focus or distract them; music energises, comforts, motivates, and inspires ${ }^{47}$ When former RUF combatants described how music helped them to generate a desired bodily conduct to be more focused, to muster zeal, and to cope with their fears, their engagement with music did in fact facilitate a state of 'entrainment' because they ascribed perceived meanings and purpose to the musical material. ${ }^{48}$ On a different level one might argue that the commando songs did "work" as a means of creating eagerness and bravery simply because the fighters knew what kind of emotional responses the songs were supposed to generate in them. Drawing on French post-structuralist literary theorist Roland Gérard Bathes, Karin Barber suggests that dealing with 'text' (understood as an arrangement of interpretable signs by its users, including music) entails a certain level of engagement, interpretation and social agency in that it 'stimulates the reader to do his or her own acts of creation, stimulated but not constrained by the text' in order to generate meaning from it. ${ }^{49}$ Steven Feld echoes this notion in saying that 'all musical sound structures are socially structured in two senses: they exist through social construction, and they acquire meaning through social interpretation'. ${ }^{50}$

Although RUF combatants were unable to grasp the meaning of the Gio lyrics, they perceived the songs as no less effective in terms of motivating them for battle and creating zeal in them as a preparation for battle. The following two quotes by the same former RUF combatant draw on several features mentioned above to do with the image of Gio combatants and by linking them to the commando songs: their reputation as fierce warriors, their ostensible lack of a revolutionary consciousness when they were deployed in Sierra Leone and the application of their appealing song repertory which endowed RUF combatants with bravery and helped them manage emotions of fear:

It [the commando song repertory] was not originated [originally] from Sierra Leone. They were Gio but this used to give us energy, zeal. Extra zeal to fight. You know, the Gio guys, against all other faith they have but, they are very brave and they can make you extra-brave when you are going to confront the battle, understand? [...] You start picking [up a song], you know, you become zealous. You can't be afraid of anything. You can be singing until you enter the [targeted] town. (Interview with F., former RUF combatant, Freetown, $17^{\text {th }}$ December 2011) So you know, [...] even [when] we are going to [the] frontline, we used to sing. That was one of the thing[s] of the Liberians I like. They make you brave. For instance, that was, that is the frontline. [points to a building in the far distance] That house there. From here we start singing, you know? We start singing, even when we open fire, we start singing. So it make[s] you brave, you forget about, in fact that you are going to die or whatever. You know, [we forget] that we are going to a dangerous place. You know. [...] I liked these, these songs.

(Interview with F., former RUF combatant, Freetown, $22^{\text {nd }}$ January 2011)

Many of the former RUF fighters stressed the appeal of the songs' intonation and spoke of the attractiveness of the 'Liberian flavour' or the 'Liberian twist' of the Gio commando songs.

With regard to the civilian population, the songs' attractiveness also played a role, albeit in the Liberian conflict, on another level. Former NPFL fighters and Liberian citizens reported that in the early days of the war, many civilians unknowingly exposed themselves to danger and some consequently lost their lives to stray bullets because they 
were captivated by the beautiful singing and dancing of Gio fighters they encountered which caused them to momentarily forget about the hazards of war. ${ }^{51}$

Although the Gio commando songs were probably less systematically put in place to thoroughly regulate the Sierra Leonean combatant's stance than Gier's examples from the First World War suggest, the boastful and confident character of many of the morale booster songs clearly conveyed the image and ideals of relentlessness, fearlessness, and readiness to inflict violence. Despite their apparent lack of ideology, these glorified features of the soldier seemed to be epitomised and realised in the Gio fighter. When singing the commando songs of these admired fighters it is possible that RUF combatants were particularly charged with morale and felt closer to living up to these ideals. Significantly, the commando songs focused on successful manoeuvres, victories in battle, and praising superiors. In line with obscuring the realities of war, even the shock of casualties was, for soldiers' purposes, positively transformed into enticing determination and mercilessness when for example looking at the song 'Zolo wapi zolo', which will be dealt with further below.

The self-defence militia faction of the Mende-speaking Kamajors defending their communities against RUF attacks had a song called 'Ma mbolateilo sina' to announce their next attack or the slaughter of captured enemies. 'Ma mbolateilo sina, ah ngiedatete walei sinah oh' means 'We have to slaughter tomorrow, very early in the morning. We are going to slaughter'. Both Kamajors and captives considered this song to be very dangerous and potent because of its explicit and brutal nature. Not only was the singing of the song a means to gather the troops for the coming bloodshed, captives would also be present when their killing was announced for the next day. Significantly, the articulation and execution of violence seems to be made more acceptable when announced, wrapped in, and expressed through song.

One of the most prominent Gio song examples with RUF combatants was a song that referred to the importance of magical charms, which would protect the fighters from harm in battle. The song 'San $\mathrm{n}$ ka u ye goo ba' can be translated as 'Miss me, but hit goe'. Goe is a strong and robust type of hardwood tree, which particularly grows in the rain forest of Nimba County. ${ }^{52}$ Initially, 'San $\mathrm{n}$ ka u ye goo ba' was a brief chant or shout which was quickly uttered when expecting or facing imminent danger. By exclaiming this incantation, the speaker is redirecting the danger of bullets coming at him away from himself; instead the bullets will hit the 'goe' tree. Moreover, to render the invocation potent, it is accompanied with offensive speech such as the naming of private parts, which is considered very shameful but adds an effective shock value to it. A former Prince Johnson INPFL recruit and trainee claims that once the statement has been made, the combatant could even walk towards the source of danger unscathed. It is crucial, however, not to retreat and never to turn one's back on the source of the gunfire. The warning to not turn one's back on the enemy is also a recurring theme in several Sierra Leonean war songs. The grassroots self-defence faction of the Mende-speaking Kamajors had a popular song called 'Mbawote', which can be translated as 'Don't turn your back'. The song warned that the magical protection would cease if combatants turned their back on the enemy in combat, but given the factional fluidity of all fighters later in the war, it also meant to caution combatants not to change sides and collude with opposing factions.

51 A former RUF combatant elaborates on his knowledge and remembers the believed impact of the song 'San $\mathrm{n}$ ka u ye goo ba': 
[...] For example, in the field, in fact, when the gun sound is heard, you sing 'zangha leguwa', ${ }^{53}$ that is, that really keeps you alert and that you should not move... you should not retreat, [it was] inspiring zeal in you, to really to stay in combat in that situation. Like that.

(Interview with M., former RUF combatant, Kailahun, $13^{\text {th }}$ Nov 2010) $\mathrm{n}$ ka u ye goo ba' or referring to the kind of protective power it occupied. These protections are more generally subsumed under the term 'bu seay', which means 'damager' or 'destroyer of bullets'. Sometimes the talisman cut into the flesh in which a special magical powder was applied to ensure the protection from projectiles. When Doe's soldiers learned that the rebels allegedly possessed magical powers of invincibility and invisibility, many of them would desert their posts in fear. The use of 'bu seay' played such a crucial role during the Liberian war that NPFL combatants would recruit medicine men among their rank and file to ensure the continuous renewal and effectiveness of their charms. ${ }^{54}$ The protective measures were so essential to the rebel faction that it inspired the composition of a simple song dedicated to the supernatural powers.

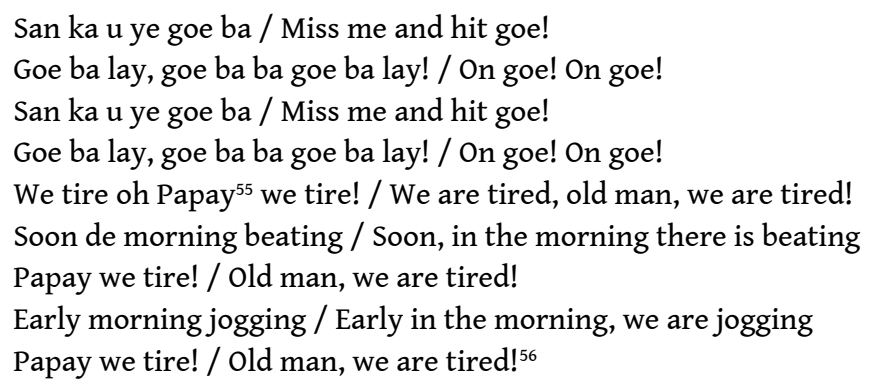

The song excerpt also draws on the arduous and brutalising military training in camp, which was supposed to desensitise the fighters for combat. The song combines a sung version of the incantation to conjure up the supernatural powers of the body protections, but also evokes the complaint of hardship.

To conclude with a final example, the song 'Zolo wapi zolo' was another tune, which existed as part of village dances and soccer competitions prior to the war. ${ }^{57}$ In the village context, young men and women would negotiate their problematic relationships and seek redress and vengeance through song and dance. The dance set-up confronts the (former) partner with his or her wrongdoings. Young women might express their anger in a sexually graphic way, singing 'You seen me naked, you can't go like that' etc. as in 'you can't get away with that'. Young males may respond by singing 'I buy you clothing, you can't go like that' etc. In the context of soccer competitions the song centred on issues of winning and losing the game. The song was particularly meaningful, when the group singing it had already faced defeat before. The song is basically a revenge song and its lyrics have been reworked to match the war context, announcing that casualties will be avenged.

\footnotetext{
You can't go eh - no!

You kill my mother

You can't go like that

Zolo wa, zolo wapi zolo

You can't go eh - eh!

You kill my father

You can't go like that

Zolo wa, zolo wapi zolo

You can't go eh - no!
} 
You kill my pikin [child]

You can't go like that

Zolo wa, zolo wapi zolo

You can't go eh - eh!

You kill my people $[. . .]^{58}$

55 professionally recorded and popularized by pop musician Friday Belleh. Belleh, or 'Friday the Cellphone Man', as he is known in Liberia, made use of the tune referring to popular culture. In his version of the song, he also sings about love relationships gone sour. Typically, older, established married men sponsor and financially provide for their considerably younger girlfriends in return for sexual favours. The song describes the dynamics of young women exploiting and outsmarting their sugar daddies. 'Zolo wapi zolo' picks up on this issue and assumes the position of the male part by saying 'You eat [spent] my money, you can't go like that', 'I buy you cell phone, you can't go like that', 'I pay your school fees, you can't go like that' etc. Despite the fact that the song played a prominent role within rebel factions during the Liberian war, the tune preserved its popular appeal. Belleh neither seems to make any political statement nor lean towards rebel sympathy in choosing this tune. Rather the song and its reception emerged unscathed from its war appropriation and therefore made it suitable for large-scale popularization.

\section{Closing Remarks}

Music plays an essential role in the creation of a collective experience in conflict settings, keeping troops motivated, zealous, obedient, and focused. Music frames drill and victories, accompanies provocations, and allows for commemoration and the expression of sentimental and nostalgic feelings of home and loss of lives. The examples of Gio commando songs have demonstrated the diverse ways in which music was appropriated and utilized in the Liberian and Sierra Leonean war. Due to the regional and ethnic recruitment of Gio combatants and their later posting to Sierra Leone, their song repertory has ultimately coined and dominated the sound of two insurgencies.

Several processes seem to be in play and need to be differentiated with regard to the reception of the Gio commando songs. At a basic level, the songs' musical and structural properties (catchy, rhythmic tunes, participatory set-up, etc.) allow for a general stimulation of 'muscular bonding' and ultimately contribute to a shared sense of cohesion through the act of joint singing and moving in unison. The structural features help to make the songs suitable for the creation of zeal, morale, and solidarity within the rank and file. Given the diverse origins of the borrowed songs, this seems to be achieved irrespective of whether the songs were originally war songs and no matter whether the lyrics can be understood or not. Although the borrowed tunes stem from other cultural practices ('soccer rivalries' etc.), Liberian fighters applied them in a - albeit considerably more serious and violent - somewhat similar context ('war rivalries'). 

Leonean troops however. But despite the apparent language barrier, the commando songs can nevertheless be applied as a means to generate zeal and a sense of camaraderie because fighters embed and place them within a context of use, namely military training, and more generally, war. The combatants make use of associations they ascribe to the songs and in this way transcend the lyrics in order to render them potent for their own situation. Moreover, they seem to charge and empower themselves through songs by drawing on their knowledge of what responses these songs are supposed to generate, or, more importantly, what they need them to facilitate. The Gio commando songs, irrespective of whether lyrics were understood, assembled RUF fighters to bond over a shared musical knowledge, which ultimately contributed to the powerful experience of in-group/out-group dynamics. Due to the connection between the songs originating from the Gio ethnic group and the imagery of the Gio fighters' prowess, Sierra Leonean fighters were particularly encouraged by the songs to follow suit and match the Gio fighters' reputation of fierceness, and may even have felt charged with similar combat skills through the singing of their songs.

The adaptation of song material from other cultural practices within Gio society is as much obvious as it is resourceful. It is noteworthy, however, that the songs' transfer across geographical and linguistic boundaries did not impair their reception by and effectiveness with Sierra Leonean fighters. This clearly reveals music's efficacy beyond its lyrics, content, and origin, and points to human agency and imagery, rather than to music's intrinsic, "universal" properties, to stimulate physical, cognitive, and emotional responses that foster social cohesion.

\section{NOTES}

1. For detailed analyses of the Sierra Leonean conflict, its root causes and its account, see RICHARDS, Paul, Fighting for the Rainforest: War, Youth and Resources in Sierra Leone, Oxford, James Currey, 1996; RICHARDS, Paul, The Social Life of War: Rambo, Diamonds and Young Soldiers in Sierra Leone, Track Two 8, No.1, 1999 [online] < http://reference.sabinet.co.za/webx/access/ electronic_journals/track2/track2_v8_n1_a5.htm> [Accessed 12 January 2014]; RICHARDS, Paul, Against Ethnicity - Some Anthropological Arguments. Conference on Rethinking Ethnicity and Ethnic Strife: multidisciplinary perspectives, Central European University, Budapest 25th-27th September 2008; PETERS, Krijn \& RICHARDS, Paul, "Youths in Sierra Leone: 'Why We Fight'", Africa. Journal of the International African Institute, 68 (2), 1998, p. 183-210; HOFFMAN, Danny, The War Machines: Young Men and Violence in Sierra Leone and Liberia (Cultures and Practice of Violence), Durham/London, Duke University Press, 2011; PETERS, Krijn, War and the Crisis of Youth in Sierra Leone, International African Library, Cambridge, Cambridge University Press, 2011; KEEN, David, Conflict and Collusion in Sierra Leone. Oxford: James Currey, 2005; GBERIE, Lansana, A Dirty War in West Africa: The R.U.F. and the Destruction of Sierra Leone, London, C Hurst \& Co. Ltd, 2005; DENOV, Myriam, Child Soldiers. Sierra Leone's Revolutionary United Front, Cambridge, Cambridge University Press, 2010; ABDULLAH, Ibrahim (ed.), Between Democracy and Terror: The Sierra Leone Civil War, Dakar, CODESRIA, 2004; TRUTH \& RECONCILIATION COMMISSION, Witness to Truth: Report of the 
Sierra Leone Truth \& Reconciliation Commission, Vol. Three A, 2004, [online] <http:// www.sierraleonetrc.org/> [Accessed 12 January 2014].

2. Other endemic warring factions involved in the Sierra Leonean war were the Sierra Leonean Army (SLA), the grassroots militia forces eventually subsumed as the Civil Defence Forces (CDF) established and spearheaded by Mende-speaking Kamajors, and later the Armed Forces Revolutionary Council (AFRC) junta, joined forces consisting of SLA splinter groups and RUF combatants.

3. RUF/SL, "Footpaths to Democracy: Towards a New Sierra Leone", [online] <http://www.sierraleone.org/AFRC-RUF/footpaths.html> [Accessed 25 January 2014].

4. TRUTH \& RECONCILIATION COMMISSION, op. cit., p. $549 \mathrm{ff}$.

5. KEEN, David, op. cit, discusses in detail the dynamics of emerging war economies in lowintensity conflicts.

6. See for example ABDULLAH, Ibrahim, Between Democracy and Terror, 2004; KING, Nathaniel, Conflict as Integration. Youth Aspiration to Personhood in the Teleology of Sierra Leone's 'Senseless War', Uppsala, Nordiska Afrikainstitutet, 2007.

7. For a debate on 'greed or grievance' as driving forces in civil wars see COLLIER, Paul \& HOEFFLER, Anke, Greed and Grievance in Civil War, The World Bank Policy Research Working Paper 2355, 2000; COLLIER, Paul, "Doing Well Out of War: An Economic Perspective", BERDAL, Mats and MALONE, David M. (eds.), Greed and Grievance: Economic Agendas in Civil Wars, Boulder, Lynne Rienner, 2000, p. 91-111.

8. ABDULLAH, Ibrahim, "Bush Path to Destruction: The Origin and Character of the Revolutionary United Front/Sierra Leone", The Journal of Modern African Studies, 36: 2, 1998, p. 203-235; ABDULLAH, Ibrahim and MUANA, Patrick, "The Revolutionary United Front of Sierra Leone. A Revolt of the Lumpenproletariat", CLAPHAM, Christopher (ed.), African Guerillas, Oxford, James Currey, 1998, p. 172-193.

9. KAPLAN, Robert D., "The Coming Anarchy”, Atlantic Monthly, February, 1994, p. 44-76; KAPLAN, Robert D., The Ends of the Earth: A Journey at the Dawn of the 21st Century, New York, Random House, 1996.

10. RENO, William, Corruption and Politics in Sierra Leone, Cambridge, Cambridge University Press, 1995; RICHARDS, Paul, Fighting for the Rain Forest, op. cit.

11. PETERS, Krijn \& RICHARDS, Paul, op. cit.

12. KANDEH, Jimmy D., "The Criminalization of the RUF Insurgency in Sierra Leone", ARNSON, Cynthia J. \& ZARTMAN, I. William (eds.), Rethinking the Economics of War. The Intersection of Need, Creed, and Greed, Washington, Woodrow Wilson Center Press, Baltimore, Johns Hopkins University Press, 2005, p. 84-106.

13. I conducted interviews in the provincial towns Kailahun, Bo, Kenema, Makeni, and the capitol city Freetown. I also interviewed several (former) SLA soldiers, AFRC combatants, members of the Kamajors/CDF, and war-affected civilians.

14. I am aware of the fact that the terms Gio and Mano are misnomers. However, I will use these terms in accordance with the terminology used by my interlocutors.

15. For a detailed account of the Liberian civil war, see e.g. ELLIS, Stephen, The Mask of Anarchy. The Destruction of Liberia and the Religious Dimension of an African Civil War, New York, New York University Press, 1999; ELLIS, Stephen, "Liberia 1989-1994: A Study in Ethnic and Spiritual Violence”, Africa Affairs, No. 94, 1995, p. 165-197; UTAS, Mats, Sweet Battlefields. Youth and the Liberian Civil War, Uppsala, Uppsala University Dissertations in Cultural Anthropology, 1, 2003.

16. GBERIE, Lansana, War and State Collapse: The Case of Sierra Leone, Theses and Dissertations (Comprehensive), Paper 30, Waterloo, Wilfried Laurier University, [online] <http:// scholars.wlu.ca/etd/30/> [Accessed 12 January 2014], 1998, p. 73ff.

17. Personal email communication with Liberian Gonwo Tyndale Dahnweih, $11^{\text {th }}$ April 2013. Mr. Dahnweih conducted several interviews on my behalf in the US with regard to the Gio culture 
and more specifically the NPFL/RUF commando songs. Mr. Dahnweih's Liberian interviewees confirm the notion of the Gio's musical superiority. I am very grateful to Gio [Dan] speaker Gonwo Tyndale Dahnweih, several former NPFL and INPFL combatants and some Liberian civilians now living in the US who experienced the Liberian war. They provided translations for as well as valuable background information on the Gio commando songs in question.

18. ELLIS, Stephen, The Mask of Anarchy, op. cit., p. 93.

19. See e.g. KEEN, David, op. cit., p. 37; TRUTH \& RECONCILIATION COMMISSION, op. cit., p. 97. There were more strategic motives at play enticing Taylor to support the RUF rebellion in order to destabilize the neighbouring country. Sierra Leone's Lungi airport and naval base was at ECOMOG's disposal as an airlift and harbour to launch attacks on NPFL-held zones in Liberia. Moreover, by providing manpower, weapons, ammunition, and other logistical support, Taylor secured the financing of his own war through the trafficking of illicit Sierra Leonean diamonds the RUF issued in return.

20. See e.g. KEEN, David, op. cit. Another important aspect was the lack of political authority within the movement early on in the war. Due to internal rivalries, the leadership killed intellectuals and ideologically driven moderates who initially spearheaded the RUF rebellion. For a discussion to explain the extreme violence of the Sierra Leonean conflict see for example KEEN, David, "Since I am a dog, beware of my fangs": Beyond a 'Rational Violence' Framework in the Sierra Leonean War, Crisis States Research Centre working papers series 1, 14, London School of Economics and Political Science, London, 2002, [online] <http://eprints.lse.ac.uk/28296/> [Accessed 12 January 2014]; KEEN, David, Conflict and Collusion in Sierra Leone, op. cit.; RICHARDS, Paul, Fighting for the Rain Forest, op.cit.; RICHARDS, Paul, "Emotions at War: A Musicological Approach to understanding atrocity in Sierra Leone", Perri 6, RADSTONE, Susannah, SQUIRE, Corinne \& TREACHER, Amal (eds.), Public Emotions, Basingstoke, Palgrave, 2007; GBERIE, Lansana, A Dirty War in West Africa, op. cit.; ABDULLAH, Ibrahim, "Bush Path to Destruction", op. cit.

21. See e.g. FARMER, Henry George, Memoirs of the Royal Military Band. Its Origin, History and Progress. An Account of the Rise of Military Music in England, London/New York, Boosey \& Co., 1904, p. 5ff.; KOPSTEIN, Jack \& PEARSON, Ian, The Heritage of Canadian Military Music, St. Catharines, Vanwell Publishing Limited, 2002, p. 3ff.

22. SHELEMAY, Kay Kaufman, "Musical Communities: Rethinking the Collective in Music", Journal of the American Musicological Society, Vol. 64, No. 2 (Summer 2011), p. $349 f$.

23. EYERMAN, Ron \& JAMISON, Andrew, Music and Social Movements: Mobilizing Tradition in the Twentieth Century, Cambridge, Cambridge University Press, 1998, p. 7, $23 f$.

24. Ibid., p. 163.

25. McNEILL, William H., Keeping Together in Time. Dance and Drill in Human History, Cambridge, Harvard University Press, 1995.

26. Ibid., p. 2.

27. Ibid., p. 3, 10, 51f. In his book Imagined Communities, Benedict Anderson suggests the term unisonance to describe the human experience of simultaneity and unisonality in joined singing (of, in this case, national anthems) and in so doing, facilitating the 'physical realization' of an imagined community. ANDERSON, Benedict, Imagined Communities: Reflections on the Origins and Spread of Nationalism, Verso, London/New York, 2006 [First published in 1983], p. 145.

28. McWHIRTHER, Christian, Battle Hymns. The Power and Popularity of Music in the Civil War, Chapel Hill, University of North Carolina Press, 2012, p. 13, 114, 126, 136.

29. GIER, Christina, "Gender, Politics and the Fighting Soldier's Song in America during the World War I", Music \& Politics, Vol. II, No. 1 (Winter 2008).

30. For publications on music in African conflicts see for instance LADAPO, Olufameni Alexander, "Martial Music at Dawn, Introits for Coups D'état", GRANT, M.J. and STONE-DAVIS, Férdia J. (eds.) The Soundtrack of Conflict. The Role of Music in Radio Broadcasting in Wartime and Conflict Situations, Hildesheim/Zurich/New York, Georg Olms Verlag, 2013, p. 197-209; AGU, Ogonna, "Songs and 
War: The Mixed Messages of Biafran War Songs", African Languages and Cultures, Vol. 4, No. 1, The Literatures of War, 1991, p. 5-19. For what are now classic case studies on praise poetry see for example CHARRY, Eric, Mande Music. Traditional and Modern Music of the Maninka and Mandinka of Western Africa, Chicago, University of Chicago Press, 2000; HALE, Thomas A., Griots and Griottes. Masters of Words and Music, Bloomington, Indiana University Press, 1998; ERLMANN, Veit, Die Macht des Wortes: Preisgesang und Berufsmusiker der Fulbe des Diamaré (Nordkamerun), Hohenschäftlarn, Klaus Renner Verlag, 1980. For publications on music as politics in African contexts see for example ANSELL, Gwen, Soweto Blues: Jazz, Popular Music, and Politics in South Africa , New York/London, Continuum, 2005; TURINO, Thomas, Nationalists, Cosmopolitans and Popular Music in Zimbabwe, Chicago and London, University of Chicago Press, 2000; ASKEW, Kelly M., Performing the Nation. Swahili Music and Cultural Politics in Tanzania, Chicago and London, University of Chicago Press, 2002; OLWAGE, Grant (ed.), Composing Apartheid. Music for and against Apartheid, Johannesburg, Wits University Press, 2008; OLANIYAN, Tejumola, Arrest the Music! Fela and his Rebel Art and Politics, Bloomington, Indiana University Press, 2004.

31. BARBER, Karin, "Text and Performance in Africa", Bulletin of the School of Oriental and African Studies, University of London, Vol. 66, No. 3, 2003, p. 324-333; COPLAN, David B., "History is Eaten Whole: Consuming Tropes in Sesotho Auriture”, History and Theory, Vol. 32, No. 4, Beiheft 32: History Making in Africa, 1993, p. 80-104; BARBER, Karin (ed.), Readings in African Popular Culture, Bloomington, Indiana University Press, 1997.

32. See for example, classic albeit generalising works on the study of African music such as NKETIA, J. H. Kwabena, “The Musical Heritage of Africa”, Daedalus, Vol. 103, No. 2, Slavery, Colonialism, and Racism, Spring 1974, p. 151-161; NKETIA, J. H. Kwabena, The Music of Africa, New York/London, W. W. Norton \& Company, 1974; CHERNOFF, John Miller, African Rhythm and African Sensibility. Aesthetics and Social Action in African Musical Idioms, Chicago and London, University of Chicago Press, 1979.

33. Agu states that in the Biafran war, songs were adopted from Igbo traditional war songs and from Christian song repertoire. AGU, Ogonna, op. cit., p. 8. Eberhard Fischer's article on the role of Dan masquerades in rural Liberia suggests that competitions such as races and wrestling play a vital role in Dan community life, despite or even more so in peacetime. Youth competitions take place in an attempt to outdo one another in sporting, music, and dance, or by joining secret societies to emerge victorious and more prestigious than the opponent. FISCHER, Eberhard, "Dan Forest Spirits: Masks in Dan Villages", African Arts, Vol. 11, No. 2, 1978, p. 16-23+94. Nketia gives some general examples of contesting, boastful, and judicial songs in other African societies and provides, in more detail, a Ghanaian example of a yearly festival, which allows for publicly articulating criticism, insults, and aggression through song. See NKETIA, Kwabena, "The Musical Heritage of Africa", op. cit., p. 153. For Klusen's discussion of the term folk song [Volkslied] see KLUSEN, Ernst, “Das Gruppenlied als Gegenstand”, Jahrbuch für Volksliedforschung, 12. Jahrg., 1967, p. 21-41.

34. There were also some Sierra Leonean commando song compositions, but they were few in number compared to the Gio commando songs, which remained popular with the pioneering recruits throughout the whole course of the war. The Mende composition 'Jigbikormah, kwei mugbwah wei', however, is one such example. The song keeps fighters alert by saying that 'There is no sleep in war because the war has displaced us'. The song also echoes sentimental feelings regarding the repercussions of the war. Another Sierra Leonean composition draws on a Temne (an ethnic group in Sierra Leone) proverb. The song 'Empty bag cannot stand' voices the combatants' complaints to their superiors for having received poor rations.

Elsewhere (NUXOLL, Cornelia, “'They listened to it because of the message.' Juvenile RUF Combatants and the Role of Music in the Sierra Leone Civil War", BRAVO, Gwyneth \& HARBERT, Benjamin J. (eds.), Music of War. Global and Transnational Perspectives, London/New York, Routledge, 2014 [forthcoming]), I have discussed the role of roots reggae music among RUF 
combatants as a means of legitimising their active involvement in the war. RUF fighters linked their felt injustices to themes raised in reggae songs. Peddie et al. suggest that the consumption of reggae music may already serve as a means of political participation and resistance. See PEDDIE, Ian (ed.), The Resisting Muse: Popular Music and Social Protest, Aldershot, Ashgate, 2006.

35. Link to song excerpt via soundcloud stream available online: http://snd.sc/18ob0v5

36. $\mathrm{L}$ marks the lead singer's lines, $\mathrm{R}$ marks the choral response.

37. This is again the Sierra Leonean spelling and pronunciation of the Gio song ' $E$ zo lo wah $\mathrm{e}$ gay'.

38. See e.g. SADIE, Stanley and TYRELL, John, "Contrafactum", The New Grove Dictionary of Music and Musicians, Second Edition, Vol. 6, Claudel to Dante, Grove, Macmillan Publishers Ltd., p. 367-370. The recorded use of contrafacta dates back to the $12^{\text {th }}$ and $13^{\text {th }}$ century. Oettinger shows how Protestant reformers of the $16^{\text {th }}$ century were keen on providing befitting music to draw more followers and bestow their church services with appropriate musical accompaniment. They borrowed extensively from sacred Catholic music and secular pieces. See OETTINGER, Rebecca Wagner, Music as Propaganda in the German Reformation, Aldershot, Ashgate, 2001.

39. See also M.J. Grant's contribution Pathways to Music Torture in this very issue.

40. AGU, Ogonna, op. cit., p. 5.

41. McWHIRTHER, Christian, op. cit., p. $2 \mathrm{f}$., $16,62 \mathrm{f}$., 75 , 82. Similarly, in the $20^{\text {th }}$ century, the National Socialists borrowed extensively from the 1920s song repertoire of the socialist labour movement (Arbeiterbewegung) as well as lansquenet songs and pieces from the German scout movement (Bündische Jugend and Wandervögel). The Nazis were aware of advantages of using songs already known to the general public from other political and cultural contexts. Not only could they easily and swiftly disseminate their political agenda, they would also be able to undermine the efforts of political adversaries by disappropriating their songs. See DITHMAR, Reinhard, "Das 'gestohlene' Lied. Adaptionen vom Liedgut der Arbeiterbewegung in NS-Liedern", NIEDHART, Gottfried \& BRODERICK, George (eds.), Lieder in Politik und Alltag des Nationalsozialismus , Frankfurt am Main, Peter Lang, 1999, p. 17-34.

42. An obvious example of lyrics changes as a result of the local transfer from Liberia to Sierra Leone would be changing the names of NPFL commanding officers and control zones located in Liberia to Sierra Leonean rebel key figures and strongholds in their respective country.

43. Link to song excerpt via soundcloud stream available online: http://snd.sc/17ni23w

44. During the war years, RUF leader Foday Sankoh frequently travelled to different rebel strongholds and commuted between Sierra Leone and Liberia. From March 1997 to 1999, he was taken under house arrest in Nigeria and held in custody for weapons violations.

45. Agu makes a similar claim stating that the adopted war songs for the Biafran war contextualised events by providing them with a link to the historical past, thus lending more credibility to the songs. AGU, Ogonna, op. cit., p. 6.

46. Several former RUF combatants described how they had developed their own ideas about what the songs possibly meant and applied their own associations to them while singing.

47. DeNORA, Tia, Music in Everyday Life, Cambridge, Cambridge University Press, 2000. MIDDLETON, Richard, Studying Popular Music, Milton Keynes, Open University Press, 1990; DeNORA, Tia, After Adorno. Rethinking Music Sociology, Cambridge, Cambridge University Press, 2003; DeNORA, Tia, Music-In-Action. Selected Essay in Sonic Ecology, Aldershot, Ashgate, 2011; SLOBODA, John, "Empirical Studies of Emotional Response to Music", JONES, Mari Riess \& HOLLERAN, Susan (eds.), Cognitive Bases of Musical Communication, Washington, American Psychological Association, 1992, p. 33-46; SLOBODA, John, Exploring the Musical Mind: Cognition, Emotion, Ability, Function, Oxford, Oxford University Press, 2004.

48. DeNORA, Tia, Music in Everyday Life, op. cit., p. 94ff.

49. BARBER, Karen, "Text and Performance in Africa", op. cit., p. 324. Emphasis in original. 
50. FELD, Steven, "Communication, Music and Speech about Music", Yearbook for Traditional Music , Vol. 16, 1984, p. 7.

51. Personal email communication with Liberian Gonwo Tyndale Dahnweih, $11^{\text {th }}$ April 2013. Music's impact was apparently not tactically used in Liberia to attract civilians or win them over for the rebel cause. In Sierra Leone however, RUF combatants sometimes used reggae songs to underline their political agenda and possibly gain voluntary followers this way. Conversely, later in the war, they also played popular local Bubu music as a means of sound blasting and as a strategy to lure citizens out of their hiding places for easy capture.

52. Other spellings for 'goe' could be 'goo' or 'goh'. Interlocutors with a NPFL or INPFL background suggested that 'goe' could also be substituted for 'guor', meaning rock.

53. 'Zangha leguwa' is the spelling literate RUF combatants provided for this song. Since they are not native Gio speakers, this is their version of what 'San $n$ ka u ye goo ba' sounded to them like.

54. Keen reports an incident where NPFL fighters deployed in the Sierra Leonean insurgency lashed out against local medicine men who refused to provide charms and bulletproof talismans for them, but willingly prepared them for the opposing civil defence groups. KEEN, David, Conflict and Collusion in Sierra Leone, op. cit., p. 39.

55. 'Papay' generally is a respectful form of addressing a senior. It was used as a courteous and affectionate name for both rebel leaders Charles Taylor and Foday Sankoh.

56. Link to song excerpt via soundcloud stream available online: http://snd.sc/1hhE3Ch

57. The Liberian interlocutors were unable to provide a translation for 'Zolo wapi zolo'. Apparently it is not a Gio [Dan] phrase, although the song is well known among Gio speakers. The phrase 'Zolo wapi zolo' probably stems from another Liberian ethnic group, which my Liberian contacts could not specify further.

58. Link to song excerpt via soundcloud stream available online: http://snd.sc/1fFovwB

\section{RÉSUMÉS}

Cet article explore le rôle des chants de commandement et de stimulation morale au sein du RUF (Revolutionary United Front/ Front Uni Révolutionnaire) durant la guerre au Sierra Leone des années 1990. En me fondant sur les résultats de mes recherches récentes, je m'intéresserai aux airs qui ont accompagné l'entraînement militaire et les activités de combat. D'une manière plus générale, il s'agira d'étudier le rôle de la musique dans la construction de la cohésion sociale et dans le renforcement des collectifs. L'article examine les moyens par lesquels les chansons provoquent des réactions physiques et émotionnelles utiles au soldat et analyse les différentes façons dont les chansons ont été réinvesties en situation de conflit depuis d'autres contextes. La majorité des chants dont il s'agit sont des contrafacta (partiels) de chants du peuple libérien Gio [Dan], provenant d'autres pratiques et contextes culturels et ayant déjà joué le rôle de chants de motivation durant la guerre civile libérienne. L'article se concentre particulièrement sur les usages de ces chants, sur leur fluidité et leur propension à être transformés ainsi que sur l'ingénuité dont font preuve les interprètes qui les recontextualisent. En mettant les chants en adéquation avec leur expérience guerrière, les combattants les rendent signifiants malgré d'évidentes barrières linguistiques et au-delà des particularités des textes.

This article explores the role of commando and morale booster songs among Revolutionary United Front (henceforth RUF) combatants in the Sierra Leone war of the 1990s. Based on recent 
research findings, it looks at the tunes that accompanied military training and combat activities and more generally examines the role of music to help generate social cohesion and sustain collectivities. The article examines how songs elicit beneficial physical and emotional responses advantageous for soldiering and it analyses the diverse ways in which songs have been reworked from other performance contexts and placed into a conflict setting. Most of the songs dealt with are (partial) contrafacta of Liberian Gio [Dan] songs, which were incorporated from other cultural practices and contexts and already played a role as motivational songs in the Liberian civil war. Special focus lies on the use of, the fluidity and formability of the songs, as well as the ingenuity of its performers to recontextualise these songs. By fitting the songs into their war experience, combatants render them meaningful despite obvious language barriers and beyond their textual properties.

\section{INDEX}

Mots-clés : guerre civile de la Sierra Leone, RUF, NPFL, chants de commandement, chants de stimulation morale, musique et texte, musique dans la guerre, contrafactum Keywords : Sierra Leone war, RUF, NPFL, commando songs, morale booster songs, music and text, music in war, contrafactum

\section{AUTEUR}

\section{CORNELIA NUXOLL}

Ethnomusicologue et anthropologue social spécialisée sur la musique de l'Afrique subsaharienne, Cornelia Nuxoll est membre du groupe de recherche « Music, Conflict and the State » à l'Université Georg August à Göttingen en Allemagne, qui se focalise sur le rôle de la musique pour promouvoir, faciliter et perpétuer des réponses violentes à des situations de conflit. 